\title{
LEBANESE POLITICAL ADVERTISING AND THE DIALOGIC EMERGENCE OF SIGNS
}

\author{
Diane Riskedahl
}

\begin{abstract}
:
This paper evaluates the role of written language in the construction of difference by looking at the emergence of two political advertising campaigns in Lebanon in 2006-2007. I will discuss how ad campaigns mounted by opposing Lebanese political factions were engaged in a battle over representing popular sentiment. Specific choices of typography, juxtaposition of codes, layout and physical placement of ads within the political landscape of urban Beirut all directly contributed to creating unique interdiscursive ideological framings for each party coalition. Due to the inter-sectarian nature of the political coalitions, the use of religious symbols was problematic in the construction of coalition identity. Other differentiating aspects such as class, patterns of consumption, and attitudes towards mourning became elemental in the creation of political distinctions and were indexically configured into this dialogue of signs.
\end{abstract}

Keywords: Political advertising; Language ideology; Lebanon.

\section{Introduction}

In driving up the southern coastal highway towards Beirut in 2006-2007, or crossing from downtown Beirut towards the Gemayze neighborhood, or riding back from the ABC department store in Dbayeh north of the capital, one was caught in the crossfire of political debate between rival coalitions which was plastered across Lebanon on outdoor advertising billboards. "I $\vee$ Life"1 (in English) proclaimed one side while right behind it "We want to live in Lebanon" (in Arabic) retorted the other in similar font and colors.

${ }^{1}$ I would like to thank Laura Miller for pointing out the need to maintain the various semiotic meanings of the heart symbol as a pictogram rather than to simply gloss it as "love". Yet, it should be noted that the campaign itself is labeled by the advertisers as the "Ilovelife" campaign. The campaign was talked about consistently using the term "hubb" in Arabic, which can mean either like or love, in both news media and among my interlocutors. But I feel that it was glossed most frequently with the more passionate connotations of "love". 


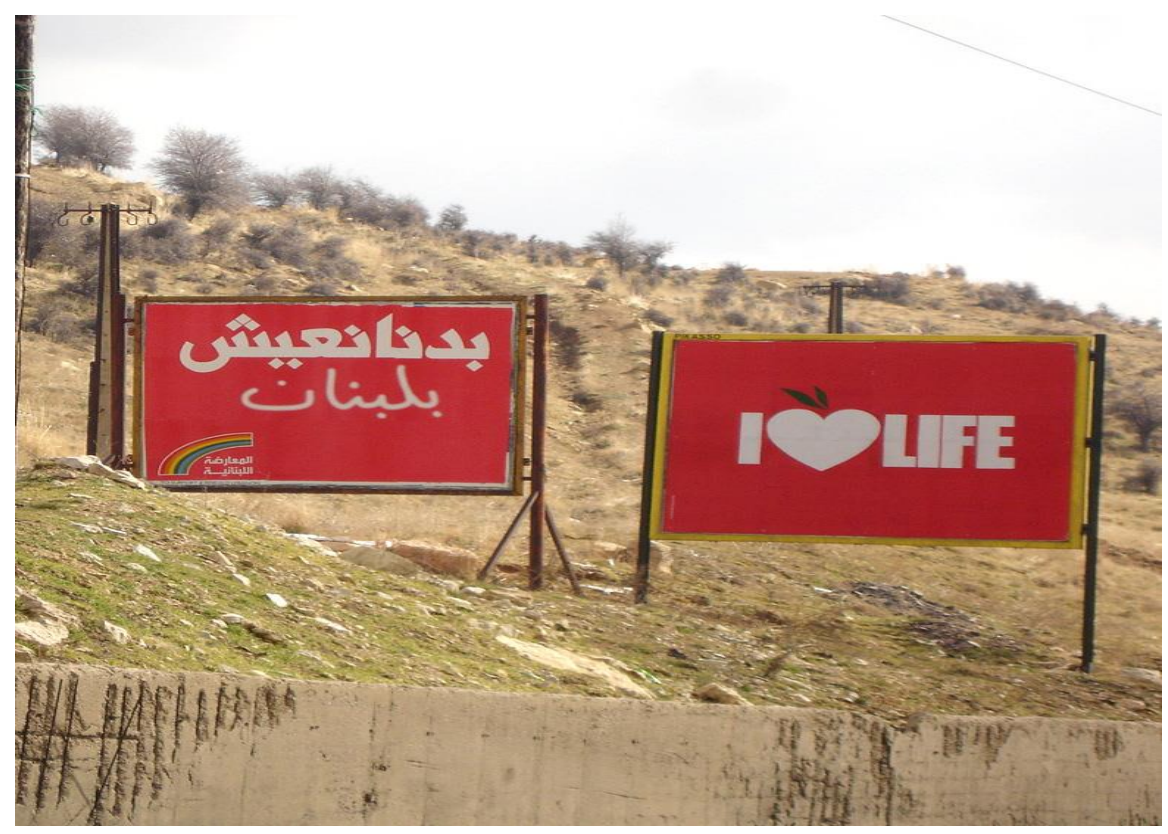

Figure 1. "badnā $n a^{c} \bar{\imath} s h b-l u b n \bar{a} n^{2 "}$ "We want to live in Lebanon', and "I love life" (Sukarieh 2007)

The two central political coalitions in Lebanon, which came to be known as the March $8^{\text {th }}$ coalition and the March $14^{\text {th }}$ coalition, had both launched massive advertising campaigns in an attempt to shepherd the war-weary citizenry back to their appropriate flocks.

This dialogue of political signage came on the heels of the summer war with Israel, which was perceived by some to be instigated by Hizbullah, the leading member of the March $8^{\text {th }}$ coalition. Power outages from destroyed power grids, rising fuel and food costs, and continued political stalemates ${ }^{3}$ had most Lebanese preoccupied with the day-to-day business of living. At the same time, or in part, because of this, these advertisements generated very strong public sentiments and caused a good deal of public discussion. The ensuing debates around dinner tables initiated by these ads indicated to me that they served as a catalyst in the process whereby individual Lebanese were determining which party they saw themselves aligned with and, perhaps more centrally, which was the right and wrong way to be Lebanese. I wondered what role, if any, these ad campaigns had in consolidating such sentiments into ideological stances.

Given that the referential meaning of these ads is not exactly controversial (who doesn't love life? and wouldn't most Lebanese want to live in their own country?), they serve as a good illustration of the importance of indexical meaning in political advertisements. The "meanings" of these outdoor ads are, of course, contextually

${ }^{2}$ Transliteration of Arabic follows the IJMES standard. Translations are my own.

3 After the installation of an interim government in the lead-up to the 2007 elections, once elections did occur, bringing in a majority of March $14^{\text {th }}$ to Parliament, the decision of the party representation in the cabinet stalled and the country was left without a president or leading ministers for many months. 
grounded in the socio-political landscape of Lebanon. Political assassinations, car bombings, war, and socio-economic disenfranchisement provide the milieu from which these campaigns emerge and in which "living" becomes a contested notion.

After anchoring this work in recent trends in linguistic anthropology in the study of language ideologies and writing systems, I begin by briefly discussing the Spring rallies of 2005 which led to the formulation of the two central political coalitions under discussion here. Due to my interest in mapping the indexical associations in the 2006-07 campaign, I focus on the creation of distinctions through calibrations of bonds of belonging. These distinctions relate to regional political affiliation, as well as to appropriate comportment in regards to mourning for assassinated members of the respective coalitions. I argue that specific choices of typography, layout, juxtaposition of codes, and physical placement of ads within the political landscape of urban Beirut all directly contributed to creating unique interdiscursive ${ }^{4}$ ideological framings for each party coalition.

\section{The creation and circulation of data: Literacy and publics}

The linguistic artifacts of outdoor advertising generate a number of theoretical concerns. In line with recent work on written language in linguistic anthropology and new literacy studies (Collins 1995; Besnier 1999; Barton 1994), this paper construes writing as a practice that must be ethnographically situated within specific socio-historical contexts. Literacy activities, such as outdoor sign production and their resulting artifacts, such as billboard ads, take the local activity of inscription into the public realm. This aspect of mediation requires attention to the notion of the public sphere in which disembodied language can be viewed as a means for political legitimation ( $\mathrm{Gal}$ and Woolard 2001). Yet I would argue, like Frekko (2009) in her discussion of public banners in a Barcelona neighborhood, that local, embodied publics and more broadly conceived disembodied publics are not necessarily separable. In the small-scale society of Lebanon ${ }^{5}$ where roughly a quarter of the population turned out for each coalition's political rally, waving signs and banners that contained a broad degree of semiotic overlay with later ad campaigns, one coherent community of practice can be discerned. At the same time, it should be emphasized that members of a community of practice are in no way uniform and that they maneuver with a sense of socially and linguistically differentiated real and potential interlocutors (Eckert 2006).

At this particular socio-historical moment in Lebanon there was a high level of social engagement of individual citizens with the broader media landscape. Khatib (2007), in discussing the role of television in the Beirut Spring, considered 2005 a watershed moment within the country for the role that the public played in both creating and commenting on the spectacles of political expression. This engagement was emblemized by the dialogue of advertising signs discussed in this paper. As Barton and

\footnotetext{
4 "Interdiscursivity operates on a different level from intertextuality in that it is genres, situations, registers social practices or communities of practice which are appropriated as significant aspects of the mediated action" (Scollon 1998: 253).

5 Lebanon had an estimated population of 4.1 million in 2008 with $89 \%$ of the population completing secondary school (2008 UN statistics).
} 
Hamilton (2005) have suggested, literacy artifacts (such as outdoor advertising) are a means by which people and activities are incorporated into larger networks of power.

In addition to the question of social context of political signs, there is the issue of their interpretation. As Collin and Stembrouck (2007) have discussed in regards to multilingual shop signs, the reading of such public signs is a "contextual act" in that accessing the "meaning" of such materials is to recognize the relevance of context. Collins and Stembrouck (2007: 337) ask: "What is the relation between particular acts or events of communication and wider or otherwise enduring social categories, cultural understandings, and forms of social organization?" I draw on the concept of linguistic ideology as the mediating link between micro and macro forms (Woolard 1998). As much work on language ideology has shown, a focus on indexicality can illuminate the processes by which linguistic form becomes ideologized as distinctive and can become emblematic of particular "types" of people (Silverstein 2003). When the uses of particular language forms begin to iconically stand for certain distinctive qualities of a group, key aspects of difference are foregrounded in intergroup relations at the loss of intragroup difference (Irvine and Gal 2000). I would like to ponder in this paper, whether the mapping of the emergence of these artifacts across time allows for a better understanding of the layering of indexical orders (Silverstein 2003) within a single sign artifact. Is it possible to trace the process of ideological change across time through the semiotic residue of advertising billboards, to uncover, as it were, their "secret life" (Silverstein 1996)?

At work in the political dialogue of signage are interdiscursive distillations of character types which become evident in the contrasting of voices amongst signs. As Agha (2005) has noted, individual voices emerge at points of contrast and it is at these junctures of distinction that one is able to recognize dialogic relations between voices. At the interdiscursive level, the interplay is one of genre or even contrasting communities of practice which respond to and evaluate the other through various means (Scollon 1998).

The advertisements in this data set share a tri-lingual (Arabic, French, and English) code repertoire. ${ }^{6}$ These three languages have a socio-politically mediated past in Lebanon. Broadly, and not exclusively, conceived historical associations include: Pan-Arabism and Islam (Arabic); French colonialism, Catholicism, and cultural elitism (French); and American Protestant missionary activity, traditional merchant class, and international business (English). Currently, these categories have become so overlapping that the distinction of language code carries no single, unified indexical association, though a recent survey of Lebanese university students' perceptions of language use showed links between religion and foreign language, namely MuslimEnglish and Christian-French associations. Additionally, Arabic was perceived as the language of everyday use and overwhelmingly associated with national identity (Shaban and Ghaith 2002). But, in the field of political advertising, due to the overlapping of coalition constituency backgrounds, it appears that codes are interchanged by both coalitions so as not to marginalize any sub-section of a coalition. As one Lebanese advertising copy writer commented to me "Dialect can play along a sectarian plane as

${ }^{6}$ While there is some play between local Lebanese dialect and formal Arabic in political advertising, it is not used as a resource in the data set under discussion here. See al-Batal 2007 for discussion of diglossia in Lebanese newscasts. 
well... but why risk to alienate your audience? ${ }^{7}$ " I argue, then, that the character types that do emerge in this dialogue of signs, including the populist Arab nationalist and the pro-western consumer, are evoked instead through other stylistic choices and indirect references.

Advertising is an extremely rich environment for the overt construction of character types. In this construction, is a dialogue between past and projected future, between consumer desires and the evocation of a desiring consumer. In the post 2006 war period in Lebanon, there was much political disenchantment among average citizens. Citizen action groups such as "bi-kaffi" (enough) and "the March $11^{\text {th }}$ group" (named for the date that lies halfway between the dates associated with the two main political coalitions) had begun to emerge to address the need for a functioning government. In this environment, politicians and advertisers alike recognized the need to re-engage the public, or more specifically rehabilitate the coalition's image, through branding campaigns. As noted by Mazzarella (2003) management of affect is central to the production of such campaigns. In fact, the Saatchi and Saatchi company hired by the March $14^{\text {th }}$ coalition to further their agenda had the stated goal on their website of moving beyond brands to "lovemarks" in order to "engender loyalty beyond reason" (Saatchi and Saatchi website). The negotiation of bonds of belonging and, in this analysis, appropriate comportment in relation to mourning are at the intersection of language and subjectivity from which individual Lebanese formulate political identities. Emotions in this context of political activity are primarily constructed not as internal subjective states, but rather as intersubjective and arguably not only between individuals, but in effect enmeshing individuals in particular social relations (McElhinney 2010). I would argue that in order to evoke a strong emotional response, it is necessary for the message to engage the historical imaginings of the audience, as well as to project a desirable future.

\section{The historical construction of difference}

In order to understand the dialogue of political signs which emerged in the 2006-2007 billboards it is necessary to return to the materialization of the two coalitions and some foundational markers of difference that surfaced in the Spring of 2005. This was a period of political change in Lebanon, which followed the assassination of the former prime minister, Rafic Hariri, on February 14, 2005. The massive car bomb targeting his convoy, which created a huge crater at the edge of the downtown central district of Beirut, generated a dynamic outpouring of popular sentiment that became channeled politically into the two opposing political alliances which are currently still firmly entrenched. These two alliances named for the dates on which they held massive public rallies following the assassination in 2005, March 8 and March 14 respectively, were formulated around the core issue of the Syrian presence in the country. The March $8^{\text {th }}$ coalition supported the Syrian role in Lebanon, while the March $14^{\text {th }}$ coalition called for the withdrawal of Syrian troops and blamed Syria for Hariri's assassination. I would argue that the images of these coalitions are intrinsically tied to their distinct representations of Lebanon during those early rallies.

\footnotetext{
${ }^{7}$ Personal interview with author, Beirut, Lebanon, May 20, 2011.
} 
At the basis of their juxtaposition is an enduring contrast in Lebanon between East and West, between Arabism and Lebanese Nationalism, in a manner which blurs the usual sectarian dichotomies. The political divide is not a Muslim-Christian divide in the traditional Western conception, but rather a local configuration of those who align themselves with Syria or against it. ${ }^{8}$ Because of this, much of the religious symbology, which may have played a role at other historical moments in the country's recent past, is to a large degree absent in the overt sense in the current party dynamics. In fact for both groups, rallies were a place for displaying multiple symbols (such as a crescent and a cross painted one on each cheek) as a means of expressing shared political commitment across sectarian lines. At the same time, since both of the main Shi'i Muslim parties, Hizbollah and Amal, were located in the March $8^{\text {th }}$ coalition, as the campaigns evolved, indirect markers of Shi'i Muslim culture became a target for the March $14^{\text {th }}$ group. ${ }^{9}$ I would argue that in an environment where the two coalition parties are both working to claim their "Lebanese-ness" where sectarian identity is not a clear marker, they are motivated to find other ways of distinguishing themselves, and at this particular time bonds of belonging tied to political alignment became central. As one Lebanese individual noted: "My own wife, who is Christian, used to be all-out for Aoun, but now, the media campaign portraying him as pro-Syrian has succeeded to turn her against him" (cited in Wimmers 2007).

\subsection{Boundaries of the nation}

During the massive political rallies at that time there was a common rallying cry of "huriyya, siyada, istiqlāl" (freedom, sovereignty, independence). The emerging March $14^{\text {th }}$ group supported the naming of their series of political rallies as "intafadat alistiqlāl" (the uprising of independence). ${ }^{10}$ They mass-produced a series of banners, signs, bumper stickers and flags with the emblem, "Istiqlāl '05, kullunā lil-watan," (Independence '05, we are all for the nation). These signs, with their red background and sprig of green, were in the colors of the Lebanese flag ${ }^{11}$ and had no overt party symbol, generating a new association for the movement. The sprig of green had a double layer of meaning evoking both the cedar at the center of the Lebanese flag, as

\footnotetext{
${ }^{8}$ Whereas the weight of the Maronite community is about equal in both camps, the vast majority of the Shi'i community (represented by Hizbullah and Amal) support the March 8 coalition, and the vast majority of the Sunni and Druze communities support the March 14 coalition. (Trablousi 2008)

${ }^{9}$ Though it is important to keep in mind that the dominant party within the March $14^{\text {th }}$ group are Sunni, like Hariri, yet they were in opposition to Syria which is a predominantly Sunni state during this period in time. This mirrors the tension between Syria and Saudi Arabia. Urban Sunnis like Hariri tend to have close financial ties with Saudi Arabia and many of them, like the Saudi regime, are broadly prowestern in their political orientation.

${ }^{10}$ Many have discussed how the organizers of early rallies that culminated in the March $14^{\text {th }}$ gathering modeled the movement after the earlier orange and pink revolutions. (Khatib 2007; Safa 2006; Traboulsi 2008)
}

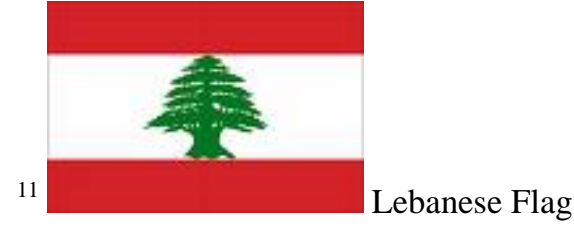


well as an olive branch symbolizing peace. In addition, this sign contributes to a nationalist character by drawing on the first line of the national anthem, "kulluna lilwatan" (we are all for the nation).

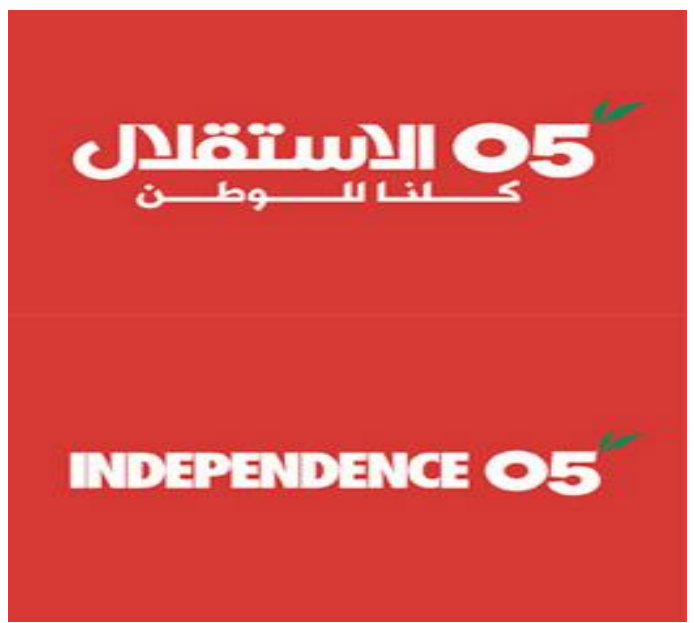

Figure 2. "Istiqlāl '05, kullunā lil-wațan" (Independence '05, we are all for the nation)

As Traboulsi (2008) has pointed out such calls for independence have historically been linked with some sort of international alliance from the 1920's onward in Lebanon. At this particular moment in 2005, the politicians capitalized on this populist refrain to distill two distinct notions of sovereignty: One which pits the local against the Syrian (rally posters stating: "100\% Lebanese" and "Syria out now") for the March $14^{\text {th }}$ coalition, and one which pits the Arab world against the west (rally posters stating "No to imperialism" or with images infantilizing the March $14^{\text {th }}$ government in relation to the US government) for the March $8^{\text {th }}$ coalition. This distinction piggybacks (though not completely) on a class division within the country of the more monied, urban class and traditionally powerful families in the ranks of March $14^{\text {th }}$, in contrast with the more historically marginalized members of society amongst the March $8^{\text {th }}$ coalition. These political alignments, March $14^{\text {th }}$ with the West and by extension global capitalism and the free market system, and March $8^{\text {th }}$ with a more Arab nationalist, antiimperialist and leftist orientation, became one of the cornerstones of difference between the two coalitions.

\subsection{Memorialization of martyrs}

In conjunction with a particular attitude towards the nation and the notion of sovereignty is a specification of the kind of emotion that one is to have in regards to the death of Hariri, and by extension the series of assassinations that occurred since the Fall of 2004, the majority of which targeted prominent figures within the party ranks of what was to become the March $14^{\text {th }}$ coalition. As White (1999: 506) has noted "acts of narrating historical events are always accompanied by metacommunicative signs that index relations between speaker, audience(s) and events represented, including emotions that mark the involvement of speakers and audiences in the narrated past." Initially, for both political coalitions there was a shared nationalist sensibility to the 
assassination. The death of Hariri was a collective blow against the nation. The waving of party flags at political gatherings was dropped and there was a fronting of red, white and green in both the clothing of participants and placards and signs. The entire country, through the process of mourning, was covered in the Lebanese flag. This was a marked contrast from other rallies I was used to attending before the Hariri assassination where people often wore the colors of their particular party. For the developing March $14^{\text {th }}$ coalition, images of Hariri also took on hyperpresent form. Makeshift shrines, articles of clothing with the image of Hariri silk-screened on them, and the uptake of the March $14^{\text {th }}$ banner or the Lebanese Flag itself, often paired with a picture of Hariri hanging from residential windows or being carried at rallies, all consolidated the notion that many Lebanese perceived the death of Hariri to be at the center of their expression of political activism.

The employment of advertising firms to further the political goals of public mourning became ubiquitous during this time. As noted by one advertiser who was a member of a special "commemoration" team at a pro-March $14^{\text {th }}$ firm: "Unfortunately whenever anybody dies, we work. Every time someone is assassinated we automatically begin a campaign so that the person's blood is not spilled in vain. We want that person to be in the minds of people" (AFP 2008). I would argue that the advertising agencies played a key role in bifurcating the nationalist sentiment along coalition lines by working to delimit the kind of memorialization and by extension emotional response that Lebanese were to have towards these political assassinations. The March $14^{\text {th }}$ camp actively blurred together the emotional response to the assassination itself with a support for the political views represented by Hariri. "Nihna $m a^{c} a k$ " (we are with you [singular]) $)^{12}$ along with "nihnna mackum" (we are with you [plural]), incorporating the other members of the coalition who have been assassinated, and the phrases "lan nans $\bar{a}$ " (we will not forget) and "ishtaqnālak" (we miss you) became omnipresent on billboards and signs throughout the country, some with images of the assassinated, others without. Additionally, quotes from traditional proverbs were used to establish this shared sense of participatory mourning, thus tying the dead into particular communities. For example, billboards stating, "shamsak lan taghīb" (your sun will not set), with a large image of Hariri were posted one after another about 50 meters apart running down the center of a local highway. The image repetition not only figuratively kept Hariri in the minds of passersby, but the steady reiteration of phrase and image generated an emotional sense of the leader's enduring presence.

Much like the commemoration of martyrdom among Hizbullah members of the March $8^{\text {th }}$ coalition, the act of mourning constructed by the March $14^{\text {th }}$ coalition becomes a public process by which members of a community assert their very membership in that community. As Deeb (2008: 381) has noted in regards to Hizbullah's construction of public displays and museums to recognize the sacrifices of

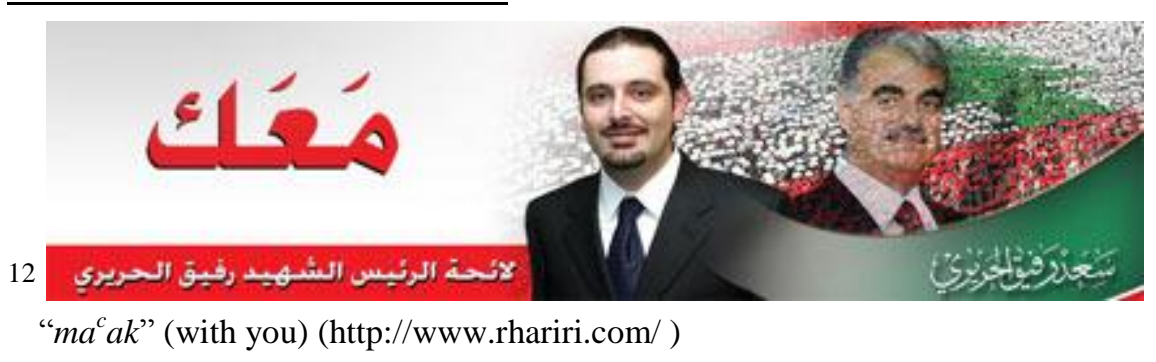


resistance fighters: "Martyrs were memorialized here with an emphasis on inclusivity and incorporation... Indeed, mourning itself is viewed as a source of community identity and solidarity." In the weeks following Hariri's assassination, more car bombings took place that targeted other members of the March $14^{\text {th }}$ coalition. With a proscribed fortyday mourning period for death, the country was in a constant state of national mourning. After a year had passed there were also yearly commemorations of each date, which worked to keep constituents almost continually involved in the memorialization process.

To suggest that one should remember, as in the slogan "lan nans $\vec{a}$ " (we will not forget), is of a different emotional register than to state "ishtaqnālak" (we miss you). At the time of the campaign many of my Lebanese interlocutors not wedded to either camp found unintended humor in these expressions of fondness or longing, particularly as they extended beyond the formal mourning period. This became even more amplified when these dispositions were reiterated for commercial purposes in 2006. For example one storefront in the Hamra district of Beirut had a March 14th sign coupled with the slogan "wallah ishtaqnālak" (by God, we miss you), in addition to a mannequin figure of Hariri present in the window. Such advertising was ubiquitous in this largely proMarch $14^{\text {th }}$ neighborhood of Beirut. It became indicative of the bifurcation of society in Lebanon at that time between the two coalitions, so marked that identifying with one coalition over another became a marketing scheme for many businesses in the country.

\section{Debating life and death}

It is in this context of death and memorialization of death that the coalitions began to debate life. The 2006-07 "ana hayat" (I life) campaign was constructed on the proposed notion that the Lebanese needed to counter the devastating effects of the 2006 war with Israel. At the start of the advertising campaign, the website dedicated to the campaign stated:

The Culture of Life is shorthand for a concept that human life, through all its stages, has to be respected above all. We understand the Culture of Life, as opposed to the Culture of Death, as a deep, well-developed sense capable of discerning true values and interpreting authentic needs in our communities and society. We want to take a stand of empowerment and embrace the change towards a new life, towards a fresh perspective that would entail new social and economic norms. (www.lebanon-ilovelife.com Italics in original)

The Saatchi and Saatchi company which undertook the campaign used the same clean, Arabic font as the "Independence '05" ad to reiterate the link with the earlier March $14^{\text {th }}$ memorial and independence campaigns. Like Helvetica in the Latin typescript ${ }^{13}$, this font has a certain ubiquitous and modern association with it. The use of the pictogram of the heart also carries a modern, hip connotation, used in text-messages and canonical in slogans such as "I $\bullet$ New York." One might also argue that it carries an element of passion beyond the lexical term "love," particularly in French and Arabic where the verb forms "hbb" or "aimer" could be glossed as either 'love' or 'like.' This

${ }^{13}$ Detailed discussion of history of the Helvetica typefont and its connotations are discussed in the documentary, Helvetica (2007) by Gary Hustwit. 
modern association, along with the solid background of red and sprig of green, directly link it with the Independence campaign, again echoing the colors of the Lebanese flag. The clean lines and lack of images create a strong message which carries over the energy of the Beirut Spring 2005 movement, while at the same time creating a break with the coalition's efforts at memorialization.

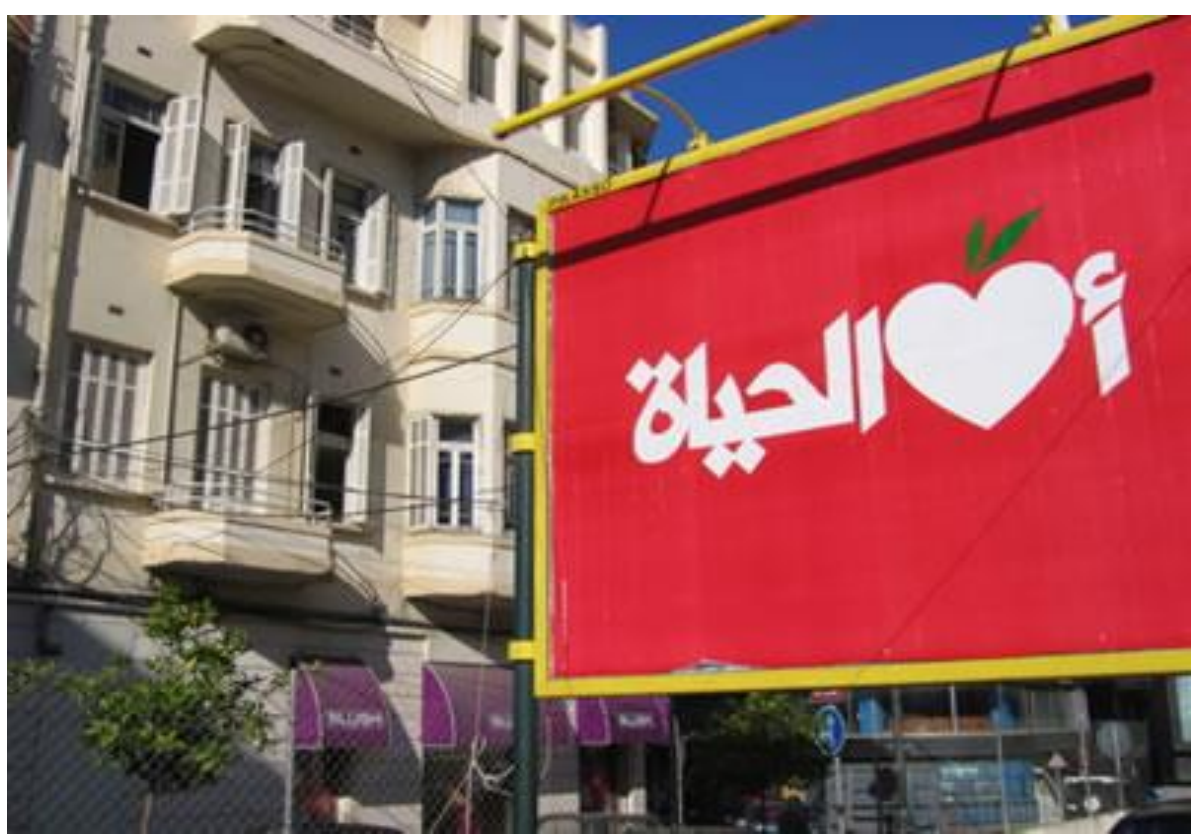

Figure 3. "a-(heart) al-hayāt" (I love life), where the initial $a$ conjugates the implicit verb in Arabic (Butters 2007).

Initially, no one claimed responsibility for these ads and while there was some ambiguity due to the shift in rhetorical tactics, none of my Lebanese interlocutors thought anyone other than the March $14^{\text {th }}$ coalition could be behind the campaign. "I $\square$ life" was a massive campaign, which placed these ads throughout Beirut and the regional suburbs at the cost of millions of dollars, partially funded, it later emerged by USAID (Sukarieh 2007). This funding lent credence to the accusation of its political opponents that it was an instrument of western powers. The first barrage of ads simply had the phrase "I $\bullet$ life" on them in Arabic, English, and French. The anonymity of this ad, combined with its lack of images or party colors, and sheer saturation of the physical environment in and around Beirut carried this campaign beyond the domain of political advertising and into the more personal domain of individual life. Much as calls to mourning were used previously, these ads interpellated readers into the social fabric of the coalition.

This shift in party message seems to be connected to the coalition and advertiser's recognition of Lebanese emotional fatigue in regards to mourning. In addition, it should perhaps be placed within the larger geo-political context of what has been referred to by Sukarieh (2012) as a "Hope Crusade", launched by the US State Department, in which the rhetoric of optimism and democracy are "brought" to regions of the Middle East which are in a constant state of unrest, thereby turning real sociohistorical injustices into cultural deficits. Sukarieh (2012) traces how the carrot of aid money intertwined with the rhetoric of hope is used in countries such as Jordan, Egypt 
and Lebanon to have local agencies partner with NGOs in order "to actively solicit popular participation in a series of guided social, political and economic reforms." The March 14 campaign, partially funded with USAID money, is laden with the type of neoliberal ideology discussed by Sukarieh in which the ideal Lebanese citizen is a modern consumer.

In contrast to the March $14^{\text {th }}$ advertisements of the previous year (prior to the 2006 war) with their focus on death and martyrdom, in this campaign, the March $14^{\text {th }}$ coalition actively asserts its distance from "death." The "I $\bullet$ life" slogan was read by the March $8^{\text {th }}$ coalition and much of the Lebanese public as a chastising of Hizbullah's perceived instigation of the war with Israel, as well as an intentional distancing from a stereotypical construction of Shi'i Martyr culture. In response, the March $8^{\text {th }}$ coalition commissioned another advertising agency, Leo Burnett, to mount an opposing campaign. The strategy of the counter-campaign consisted of both a re-voicing of the original ad and a response to it. The revoicing appropriated the key markers of color and font adopted by their adversaries and then the response was added in graffiti font to effectively subvert it.

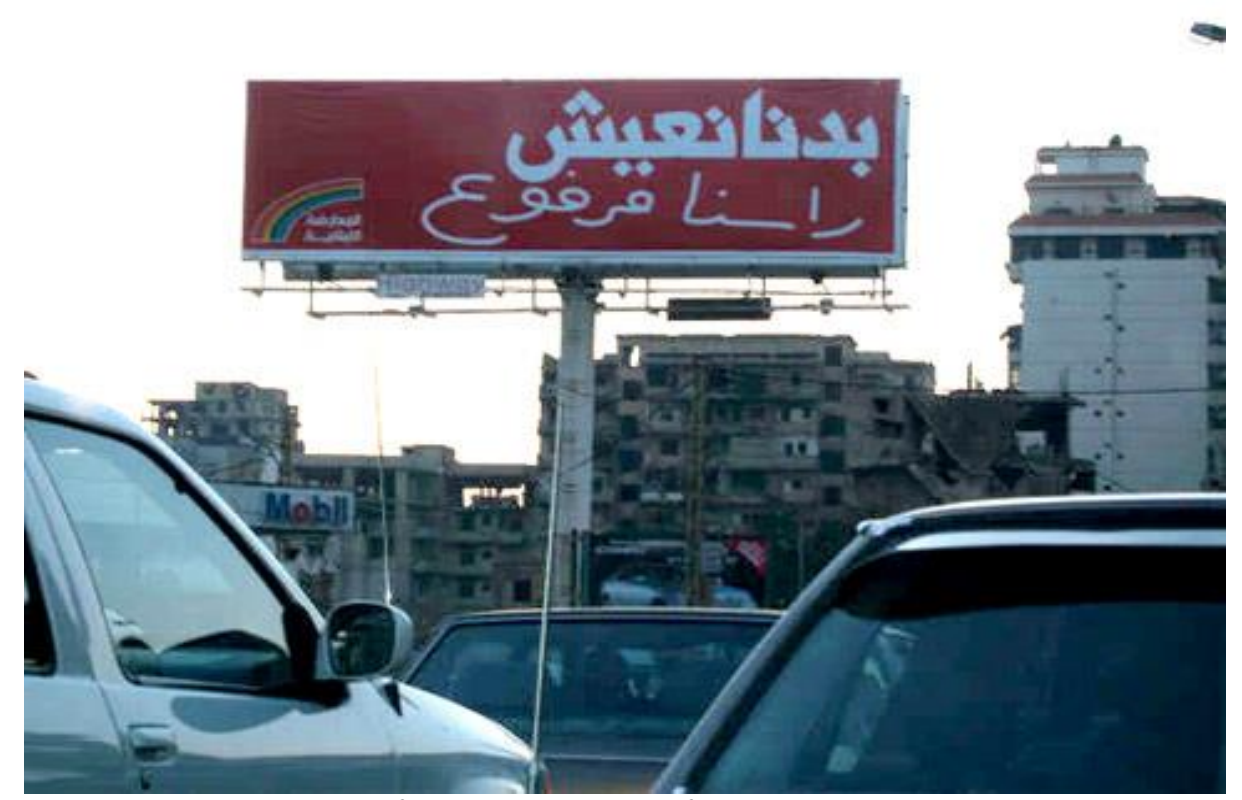

Figure 4. "badnā $n a^{c}$ ish $r \bar{a} s n \bar{a} \operatorname{marf} \bar{u}^{c}$ " (we want to live [added in graffiti-like font] with our heads raised high) (Sukarieh 2007)

In discussion with a Lebanese graphic designer about Arabic calligraphy choices in posters, he noted, "the styles reflect the different generations or different voices or the different ways of thinking and so we really take this to heart when we're thinking about how the language conveys meaning." 14 By contrasting Arabic font in these ads, the campaign makes the interdiscursive layers of political stances distinctly evident. The indexical associations of the graffiti style font evoke the distinguishing features of the March $8^{\text {th }}$ coalition in opposition to the first half of the sign. In addition, many of the ads misalign the second half of the message with the first line as another indicator of its response-like quality. Graffiti-style font in Lebanon carries with it populist and anti-

\footnotetext{
${ }^{14}$ Personal interview with author. Beirut, Lebanon, May 17, 2011
} 
establishment indexes, as it does in other areas in the region (Peteet 1996). In its efforts to paint members of the March $14^{\text {th }}$ coalition as sell-outs to Western powers and globalization by extension, this post-modern incursion of hand-written expression brings the populist message of the March $8^{\text {th }}$ coalition into full view.

There has been recent interesting work on the association with script choice and specific ideological stances in public contexts (LaDousa 2002; Angermeyer 2005; Daveluy and Ferguson 2009). Angermeyer (2005) notes how advertising seems to provide a less regulated space in terms of orthography than many other written contexts. In LaDousa's (2002) discussion of advertising for language schools in North India, he has noted how script choice of either Roman or Devanagari can interact with language choice of either Hindi or English to index specific ideological stances. In drawing on Gal and Irvine's (2000) notion of semiotic erasure, he concludes, "The end-points of advertising's combinatorial possibilities of lexical and script choice erase the semiotic possibilities of the use of both languages in such conversations; consequently, advertising exists as a somewhat self-contained system of school differentiation" (2002: 225). This contrasts with the multivariable possibilities for other products in North Indian advertising and highlights the choice by school institutions to generate a concordance between language and script which allows consumers to generate an ideal image of the school. This concordance, which can be orchestrated only through the erasure of internal difference, is a political strategy for the coalition campaigns as well.

The initial March $14^{\text {th }}$ advertisement intended to draw a clear distinction between their coalition and the March $8^{\text {th }}$ coalition in which Hizbullah is the leading party. Yet, through the concordance of color and font, March $8^{\text {th }}$ ads work to erase the ideological distinction that is being made and affirm that they too "love life," albeit under different conditions. The first line of reiteration then claims we are all Lebanese. As Hall and Bucholtz (2004) have noted, the erasure of ideologically discordant elements is a key aspect of identity formation for both the construction of sameness and difference in that the enactment of one requires the obscuring of the other. They argue, "While the main focus of Gal and Irvine's work is on the semiotics of differentiation, the ideological processes they describe, including erasure, are just as integral to the creation of similarity" (Bucholtz and Hall 2004: 495).

Through the semiotic reiteration of the March $14^{\text {th }}$ campaign signs, The March $8^{\text {th }}$ coalition lays claim to their nationalist message. Yet, it is in the second line that the response aspect of the advertisement, as alignment and font shift, where this national, modern co-construction becomes revised into the populist, leftist stance which pushes March $14^{\text {th }}$ into the margins. The graffiti font used by the Leo Burnett March $8^{\text {th }}$ campaign achieves a counter message directed at the March $14^{\text {th }}$ ads in which the populist voice of the everyman is inscribed. Indicating the ideological alignment of the political coalition with the ad campaign, representatives of two of the main parties in the March $8^{\text {th }}$ coalition, Hizbullah and the Free Patriotic Movement, made a public statement on a local Lebanese television station, asserting:

The campaign is a response to those who are accusing us that we do not want to live and that we do not love life. Unlike the 'private sector' we are saying we want to live all together, opposition as well as the pro-government parties in a Lebanon for all of us, We love life too, but we want to define what kind of life we love to live together in the country (Cited in Sukarieh 2007) 
Phrases in the counter-campaign, such as "We want to live - in security," "We $\bullet$ life with dignity", "I $\bullet$ life -- in all its colors", and "We want to live -- without debt," all indicate a commitment by the March $8^{\text {th }}$ coalition not just to any kind of life, but to one in which they stand up to Israel and western powers and in which basic human rights are extended to all members of society during a time of rampant inflation, lack of civil services and prolonged political stalemates. These slogans contain both a class critique as well as a comment regarding the fact that many regions of the country outside the urban center were largely abandoned by the government in terms of social and infrastructural development. This claim of representing all members of society is reinforced through both the labeling of March $8^{\text {th }}$ as the rainbow coalition, including the colors of both coalitions' parties (note the rainbow in the bottom left corner of the sign). Through the strategies of reiteration and then revision, the March $8^{\text {th }}$ ad campaign manages to highlight similarity and difference in their distillation of political identity which allows citizens to both identify with them, as well as counter the March $14^{\text {th }}$ position.

The initial sudden burst of the original "I $\bullet$ life" campaign across the country, in regions largely supportive of the March $14^{\text {th }}$ coalition as well as areas dominated by the supporters of the March 8th coalition, created a geo-spatial challenge to which the March $8^{\text {th }}$ counter-campaign responded. Just as the graffiti font and alignment highlighted their "uptake and response" of the "I $\bullet$ life" ads, the counter-campaign also saturated all regions of the country, but its architects often chose to physically juxtapose their ads in the landscape with those that were initiated by the March $14^{\text {th }}$ coalition (as noted in fig. 1). This created the actual physical effect of a sign dialogue, which could be read in sequence when one drove by. In Lebanon, it is not uncommon for a neighborhood or township affiliated with a particular politician or party to be plastered with posters pertaining to that individual or group. This marking of territory is something that could be viewed as a carry-over from the civil war when both graffiti and posters were used to let individuals know who controlled the area they were in (Khalaf and Khoury 1993). This physical juxtaposition of ads from opposing coalitions highlighted their ongoing battle over constituencies at that point in time. ${ }^{15}$

This dialogue then resulted in additional phases of the original March $14^{\text {th }}$ ad campaign, a sort of counter-counter-attack, which shifted to expressing all the ways that "they" loved life: "I have a class", "I'm going out partying tonight", or "I'm going to work." This contributed to a construction of affiliates as upper-middle-class, educated, professional members of society with certain material desires, wants and needs, and had the effect of heightening the distinctions that the March $8^{\text {th }}$ group was already asserting. The neo-liberal ideological orientation was evident both in first-person singular pronoun usage, as well as in some of the types of activities this Lebanese archetype was engaging in. As though to reinforce the consumerist reading of this campaign, in the months following, numerous private companies selling various commodities contributed their own variations in signs stating: "I $\bullet$ [insert the name of specific product here]".

15 In a 2009 commemoration campaign for the March $14^{\text {th }}$ coalition, it was pointed out to me how ads were now limited to strongholds of particular politicians rather then spread across the country "as if they agreed, this is my territory and this is yours. No stepping into each others territory and no elucidation of the emotions of our masses" (Sukarieh, personal communication). 


\section{Conclusion}

The materials from which commodity images are made are of course always already socially mediated; that is to say, they earn polyvalent but historically determinate accretions of reference, connotation, and indexicalities. The work of advertising wagers on generating value out of a fortuitous deployment of these resonances. But by the same token, it remains beholden to-and sometimes hobbled by the experiences it invokes. (Mazzarella 2003: 35)

Through an analysis of political outdoor advertising I have drawn on the concept of linguistic ideology as the mediating link between written language and the distillation of political identity for two political coalitions in Lebanon. In an effort to generate a political image which was not limited by sectarian identity, political coalitions and advertisers found themselves drawing on other forms of distinction in their efforts to pull together a coherent group identity across party and religious lines. This liberated them from much of the traditional rhetoric of sectarian difference anchored in the country's historical imagination. Due in part to the state ban on the incitement of sectarian tension in the country, as a result of the civil war (1975-1989) and in part due to the intersectarian make-up of the coalitions, party identity was formed through distinctions of class and regional political alliances as opposed to sectarian identity.

Constructing/evoking the proper emotions at the appropriate times was a key resource for accessing an in-group social identity. As the Leo Burnett corporation in Lebanon, which was responsible for the March $8^{\text {th }}$ coalition response campaign, noted: "Good ideas do not just circulate information. They penetrate the public mind with desires and belief" (Arab Ad 2004). The advertisements discussed here illustrate in glossy form the multi-modality of affect being employed for both validation and for political effect by the political coalitions.

During this very volatile and violent time of political assassinations and war, individual comportment in regards to death and later in response to life became the focal point through which other aspects of difference were filtered. The emotional response to the assassination of the former Prime Minister Rafic Hariri was blurred together with support for his political views in such a way that the March $14^{\text {th }}$ coalition was able to use mourning as a means for political involvement. After a period of continued assassinations and the 2006 war with Israel, the public was saturated with death. The coalitions, and advertisers they hired to represent them, worked to realign public support around the concept of "life". In an effort to coalesce a series of new associations for the March $14^{\text {th }}$ movement, "modern" font with no images and bold colors carried the message of "moving forward" out of the political stalemates and violence in which the country was mired, distilling a certain way to "live". The uptake of this topic of life by the opposing coalition rested on the notion that March $14^{\text {th }}$ had sold out their notion of national sovereignty for security within the folds of Western powers. March $8^{\text {th }}$ signs revoiced their own choice to live, through replication of font and colors. This re-voicing carried with it an effort at concordance, an effort to erase the distinction that March $14^{\text {th }}$ was trying to assert. This concordance was not left to stand alone. Once March $8^{\text {th }}$ reclaimed the notion of "life", they revised the terms which March $14^{\text {th }}$ would choose to live by, asserting instead a series of more populist and anti-imperialist interests in contrasting graffiti font. 
Stylistic variables such as graffiti-style font, layout, use of pictograms, colors, in addition to the use of first person pronouns and the geo-spatial positioning of ads, all contributed to the reading of these outdoor billboards as part of an ongoing social dialogue about the right way to "live" in the context of so much death. Lack of an overt political designation for the signs contributed to the sense that this was just a public discussion, not an orchestrated political campaign. In a similar manner in which calls to mourning were used in earlier ad campaigns, this dialogue interpellated readers into the social fabric of the coalitions.

This dialogue also highlighted the processual and often incomplete nature of political identity formation. Through the evaluation of how ideologies of national sovereignty and belonging saturate particular linguistic forms in an advertisement and how these elements of style begin to "stand for" coalition group identity - we are able to denaturalize the political process embedded in the indexical order. In this dialogue of political signage we are able to trace not only the ideological formulation of political party identity, but also perhaps the limits of the collective construction of feelings such as loyalty or grief at moments of political upheaval.

\section{References}

al-Batal, Mahmoud (2007) Identity and language tension in Lebanon: The Arabic of local news at LBCI. In A. Rouchdy (ed.), Language Contact and Language Conflict in Arabic: Variations on a Sociolinguistic Theme. Curzon Arabic Linquistic Series. New York: Routledge, pp. 89-115.

AFP Beirut (2008) Ads with an agenda: Lebanon’s battle of the billboards. March 31.

Agha, Asif (2005) Voice, footing and enregisterment. Journal of Linguistic Anthropology 15.1: 38-59.

Angermeyer, Philipp (2005) Spelling bilingualism: Script choice in Russian American classified ads and signage. Language in Society 34.4: 493-531.

Barton, David (1994) Literacy: An Introduction to the Ecology of Written Language. Oxford: Blackwell.

Barton, David, and Mary Hamilton (2005) Literacy, reification and the dynamics of social interaction. In D. Barton, and K. Tusting (eds.), Beyond communities of practice: Language, power and social context. Cambridge: Cambridge University Press, pp. 14-35.

Besnier, Niko (1999) Literacy. Journal of Linguistic Anthropology 9.1-2: 141-143.

Bucholtz, Mary, and Kira Hall (2004) Theorizing identity in language and sexuality research. Language in Society 33: 469-515.

Butters, Andrew (2007) Lebanon poster politics. Time Magazine Middle East Blog. Posted January 18, 2007.

Collins, James (1995) Literacy and literacies. Annual Review of Anthropology 24: 75-93.

Collins, James, and Stef Slembrouck (2007) Reading shop windows in globalized neighborhoods: Multilingual literacy and indexicality. Journal of Literacy Research 39.3: 335-356. 
Deeb, Lara (2008) Exhibiting the 'just-lived past': Hizbullah's nationalist narratives in transnational political context. Comparative Studies in Society and History 50.2: 369-399.

Daveluy, M., and J. Ferguson (2009) Scripted urbanity in the Canadian north. Journal of Linguistic Anthropology 19: 78-100.

Eckert, Penelope (2006) Communities of practice. Encyclopedia of Language and Linguistics. Amsterdam: Elsevier.

Frekko, Susan (2009) Signs of respect: Neighborhood, public, and language in Barcelona. Journal of Linguistic Anthropology 19.2: 227-245.

Gal, S., and K. Woolard (2001) Constructing languages and publics: Authority and representation. In S. Gal, and K. Woolard (eds.), Languages and Publics: The making of authority. Manchester: St. Jerome, pp. 2-12.

Hustwit, Gary (2007) Helvetica. London: Swiss Dots, Ltd.

Irvine, J., and S. Gal (2000) Language ideology and linguistic differentiation. In P. Kroskrity (ed.), Regimes of language: ideologies, polities, and identities. Santa Fe, New Mexico: School of American Research Press, pp. 35-83.

Khalaf, Samir, and Philip Khoury (1993) Recovering Beirut: Urban design and post-war reconstructions. Social, Economic and Political Studies of the Middle East Vol. 47. New York: Brill.

Khatib, Lina (2007) Television and public action in the Beirut Spring. In N. Sakr (ed.), Arab Media and Political Renewal: Community, Legitimacy and Public Life. London: IB Tauris, pp. 28-43.

LaDousa, Chaise (2002) Advertising in the periphery: Languages and schools in a North Indian city. Language in Society 31: 213-242.

McElhinney, Bonnie (2010) The audacity of affect: Gender, race and history in linguistic accounts of legitimacy and belonging. Annual Review of Anthropology 39: 309-328.

Mazzarella, William (2003) "Very Bombay" contending with the global in an Indian advertising agency. Cultural Anthropology 18.1: 33-71.

Peteet, Julie (1996) The writing on the walls: The graffiti of the Intifada. Cultural Anthropology 11.2: 139-159.

Safa, Oussama (2006) Lebanon springs forward. Journal of Democracy 17.1: 22-37.

Scollon, Ron (1998) Mediated discourse as social interaction: A study of news discourse. Language in Social Life Series. London: Longman.

Shaban, Kassim, and Ghazi Ghaith (2002) Research notes: University students' perceptions of the ethnolinguistic vitality of Arabic, French and English in Lebanon. Journal of Sociolinguistics 6.4: 557574.

Silverstein, Michael (2003) Indexical order and the dialectics of sociolinguistic life. Language and Communication 23.3-4: 193-229.

Sukarieh, Mayssoun (2007) We love life whenever we can. Electronic Lebanon. 5 Jan. 2007. http://electronicintifada.net/v2/article6364.shtml (last accessed June 10, 2009)

Sukarieh, Mayssoun (2012) The hope crusades: Culturalism and reform in the Arab world. Political and Legal Anthropology Review 35.1: 115-134. 
Traboulsi, Fawwaz (2008) Lebanon on the brink. In N. Hovsepian (ed.), The War on Lebanon: A reader. Northampton, Mass.: Olive Branch Press, pp. 349-357.

White, Geoffry (1991) Emotional remembering: The pragmatics of national memory. Ethnos 27.4: 505552.

Wimmers, Heiko (2007) Rallying around the renegade. Middle East Report. August 27.

Woolard, Kathryn (1998) Introduction: Language ideology as a field of inquiry. In B. Schieffelin, K. Woolard, and P. Kroskrity (eds.), Language Ideologies: Practice and Theory. Oxford: Oxford University Press, pp. 3-47.

DIANE RISKEDAHL is Assistant Professor of Anthropology at the University of Toronto, Scarborough who studies the linguistic mediation of political practices in Lebanon. Her research covers topics such as the political uses of historical memory, how the metaphor of family relations has been used in political rhetoric to negotiate Lebanese national relations with the neighboring Syrian state, and political media discourses in the Lebanese post civil war context.

Address: Department of Anthropology, University of Toronto Scarborough, 1265 Military Trail, Scarborough, Ontario Canada M1C 1A4; email: diane.riskedahl@utoronto.ca 